\title{
KEWENANGAN MENGADILI PENGADILAN HUBUNGAN INDUSTRIAL DALAM PERKARA DIREKSI MELAWAN PERUSAHAAN
}

Kajian Putusan Nomor 521 PK/Pdt/2017

\section{THE INDUSTRIAL RELATIONS COURT JURISDICTION IN THE CASE OF A COMPANY AGAINST ITS DIRECTORS}

\author{
An Analysis of Decision Number 521 PK/Pdt/2017 \\ Nindry Sulistya Widiastiani \\ Fakultas Hukum Universitas Atma Jaya Yogyakarta \\ J1. Mrican Baru 28 Yogyakarta 55281 \\ Email: nindry.widiastiani@uajy.ac.id
}

Naskah diterima: 4 Desember 2018; revisi: 19 Agustus 2019; disetujui 19 Agustus 2019

http://dx.doi.org/10.29123/jy.v12i2.349

\begin{abstract}
ABSTRAK
Penelitian ini menganalisis Putusan Peninjauan Kembali Mahkamah Agung Nomor 521 PK/Pdt/2017, dalam perkara gugatan uang jasa pengabdian dan penghargaan oleh direksi melawan perusahaannya. Pada putusan peninjauan kembali, Mahkamah Agung berpendapat bahwa perkara ini merupakan yurisdiksi dari pengadilan hubungan industrial, bukan pengadilan negeri. Pokok permasalahan dalam penelitian ini ialah mengenai apakah pengadilan hubungan industrial mempunyai yurisdiksi atas perkara a quo sebagaimana dikemukakan Mahkamah Agung. Penelitian ini bersifat normatif untuk menelaah prinsip-prinsip yang berkaitan dengan permasalahan secara mendalam. Hasil penelitian menunjukkan bahwa pengadilan hubungan industrial tidak berwenang mengadili perkara ini. Direksi di perusahaan berkedudukan sebagai perwakilan pengusaha, bukan pekerja, sehingga perselisihan antara direksi dengan perusahaan bukanlah termasuk perselisihan hubungan industrial sebagaimana diatur dalam Undang-Undang Nomor 2 Tahun 2004. Oleh karena itu, perkara ini adalah sengketa keperdataan
\end{abstract}

biasa yang merupakan yurisdiksi dari pengadilan negeri. Kata kunci: kewenangan mengadili, direksi, pengadilan hubungan industrial, pengadilan negeri.

\section{ABSTRACT}

This research aims to analyze the Supreme Court's civil request Decision Number 521 PK/Pdt/2017, in the case of honorarium devotion lawsuit and reward of the directors against his company. In this decision, the Supreme Court believes that this case is in the jurisdiction of the industrial relations court, not in the district court. The main issue in this research is whether the industrial relations court has jurisdiction over the case as stated by the Supreme Court. This normative research is to examine deeply about the principles that relate to the problem. The author concludes that the industrial relations court theoretically has no jurisdiction to handle this case. In any companies, directors are the representatives, not their workers, so that the dispute between the company and its directors is not an industrial relations dispute as stipulated in Law Number 2 of 2004. Therefore, the 
case is just a regular civil law dispute under which the district court has jurisdiction.
Keywords: jurisdiction, director, industrial relations court, district court.

\section{PENDAHULUAN}

\section{A. Latar Belakang}

Manusia selalu berhubungan antara satu sama lain, hidup berkelompok dalam masyarakat. Hal tersebut disebabkan karena manusia adalah makhluk sosial (zoon politicon), yakni makhluk yang tidak dapat melepaskan diri dari berinteraksi atau berhubungan satu sama lain dalam rangka memenuhi kebutuhannya, baik yang bersifat jasmani maupun rohani (Husni, 2004: 1). Kehidupan bersama itu menyebabkan adanya interaksi, kontak atau hubungan satu sama lain (Mertokusumo, 2010: 4). Interaksi dan kontak tersebut tak jarang berkembang menjadi konflik akibat benturan kepentingan. Di sinilah peran hukum sebagai pelindung kepentingan manusia. Apabila terjadi konflik atau sengketa, pelaksanaan penegakan hukum itu diserahkan kepada penguasa, dalam hal ini kekuasaan kehakiman (Mertokusumo, 2010: 175).

Undang-Undang Nomor 48 Tahun 2009 menyebutkan bahwa kekuasaan kehakiman merupakan kekuasaan negara yang merdeka untuk menyelenggarakan peradilan guna menegakkan hukum dan keadilan berdasarkan Pancasila, demi terselenggaranya negara hukum Republik Indonesia. Pada negara hukum Republik Indonesia, penyelenggaraan kekuasaan kehakiman tersebut dilakukan oleh sebuah Mahkamah Agung dan badan peradilan yang berada di bawahnya, serta oleh sebuah Mahkamah Konstitusi (Butarbutar, 2009: 358). Terdapat empat lingkup badan peradilan di Indonesia, yakni lingkungan peradilan umum, peradilan agama, peradilan militer, dan peradilan tata usaha negara (Mertokusumo, 2009: 21).
Selain empat lingkup peradilan tersebut, terdapat pula sistem penyelesaian sengketa berdasarkan yurisdiksi khusus (specific jurisdiction) (Harahap, 2007: 183), misalnya pengadilan tindak pidana korupsi dan pengadilan hubungan industrial. Pembagian lingkup peradilan tersebut juga mempunyai konsekuensi adanya perbedaan kewenangan mengadili, yang disebut yurisdiksi (jurisdiction) atau kompetensi, yakni pengadilan yang berwenang mengadili sengketa tertentu sesuai dengan ketentuan yang digariskan peraturan perundang-undangan (Ingman, 1996: 1).

Perbedaan pengadilan berimplikasi terdapat perbedaan kewenangan mengadili. Setiap pengadilan mempunyai kewenangan mengadili jenis sengketa yang berbeda-beda. Oleh karena itu, memperhatikan karakteristik jenis sengketa yang menjadi kewenangan suatu pengadilan tertentu menjadi penting, agar gugatan tidak salah alamat yang mempunyai konsekuensi tidak dapat diterimanya gugatan di pengadilan.

Masalah mengenai kewenangan mengadili ini terlihat pula pada salah satu kasus yang dimuat dalam Putusan Nomor 521 PK/Pdt/2017. Kasus tersebut bermula dari pengajuan gugatan seorang mantan direksi Bank Pembangunan Daerah DIY. Direksi tersebut mempersoalkan mengenai uang jasa dan pengabdian yang tidak dibayarkan oleh Bank Pembangunan Daerah DIY. Padahal uang jasa dan pengabdian tersebut mestinya merupakan salah satu imbalan yang diberikan oleh Bank Pembangunan Daerah DIY kepada direksinya, atas pelaksanaan tugas pengelolaan perusahaan. Akibat tidak adanya pembayaran uang tersebut, direksi kemudian menuntut perusahaannya, Bank 
Pembangunan Daerah DIY, ke pengadilan. Kasus ini telah diperiksa pada pengadilan-pengadilan tingkat sebelumnya dengan Putusan Nomor 54/Pdt.G/2012/PN.Yk, Nomor 09/PDT/2013/ PT.Y, dan Nomor 2788 K/Pdt/2013. Tidak puas dengan putusan kasasi, direksi tersebut kemudian mengajukan permohonan peninjauan kembali.

Pada Putusan Nomor 521 PK/Pdt/2017, Mahkamah Agung akhirnya menolak permohonan peninjauan kembali yang diajukan oleh direksi tersebut. Di bagian pertimbangan mengenai hukumnya, halaman ke-28 putusan tersebut, Mahkamah Agung menyatakan bahwa pokok sengketa antara direksi tersebut dengan Bank Pembangunan Daerah DIY merupakan kewenangan absolut dari pengadilan hubungan industrial. Mahkamah Agung tidak sependapat dengan dalil direksi yang menyatakan bahwa pokok sengketa dalam kasus ini merupakan kewenangan absolut dari pengadilan negeri, sebagaimana direksi tersebut sebelumnya telah mengajukan gugatannya kepada Pengadilan Negeri Yogyakarta. Hal ini menjadi menarik untuk dikaji apakah dalam kasus yang dimuat dalam Putusan Nomor 521 PK/Pdt/2017 tersebut seharusnya merupakan kewenangan pengadilan hubungan industrial sebagaimana dikemukakan oleh Mahkamah Agung, ataukah merupakan kewenangan pengadilan negeri sebagaimana didalilkan oleh direksi tersebut.

\section{B. Rumusan Masalah}

Bertitik tolak pada latar belakang yang telah dikemukakan pada bagian sebelumnya, dapat diambil rumusan masalah sebagai berikut: Apakah pengadilan hubungan industrial memiliki kewenangan untuk memeriksa, mengadili, dan memutus perkara gugatan uang jasa dan pengabdian antara direksi melawan perusahaannya, sebagaimana dimuat dalam Putusan Nomor 521 $\mathrm{PK} / \mathrm{Pdt} / 2017$ ?

\section{Tujuan dan Kegunaan}

Penelitian ini dilakukan dengan tujuan untuk mengkaji kewenangan mengadili pengadilan hubungan industrial pada kasus gugatan uang jasa dan pengabdian direksi melawan perusahaannya berdasarkan Putusan Nomor 521 PK/Pdt/2017.

Manfaat yang dapat diperoleh dari penelitian ini:

1. Penelitian ini diharapkan dapat memberi manfaat bagi pengembangan ilmu hukum, khususnya hukum ketenagakerjaan, hukum perdata, dan hukum acara perdata sebagai salah satu referensi tambahan yang membahas mengenai kewenangan mengadili pengadilan hubungan industrial dan pengadilan negeri.

2. Penelitian ini diharapkan memberi sumbangan pemikiran, serta menambah wawasan dan pengetahuan di bidang ilmu hukum, khususnya hukum ketenagakerjaan, hukum perdata, dan hukum acara perdata.

3. Penelitian ini juga diharapkan memberikan masukan bagi hakim sebagai sumber pemahaman tambahan dan rujukan untuk memutus perkara terkait perbedaan kewenangan mengadili pengadilan hubungan industrial dan pengadilan negeri.

\section{Tinjauan Pustaka}

1. Kewenangan Mengadili

Undang-Undang Nomor 48 Tahun 2009 tentang Kekuasaan Kehakiman mendefinisikan 
kekuasaan kehakiman sebagai kekuasaan negara yang merdeka untuk menyelenggarakan peradilan guna menegakkan hukum dan keadilan berdasarkan Pancasila, demi terselenggaranya negara hukum Republik Indonesia. Penyelenggaraan kekuasaan kehakiman tersebut dilakukan oleh sebuah Mahkamah Agung dan badan peradilan yang berada di bawahnya dalam lingkungan peradilan umum, lingkungan peradilan agama, lingkungan peradilan militer, dan lingkungan peradilan tata usaha negara, dan oleh sebuah Mahkamah Konstitusi (Butarbutar, $2009: 358$ ).

Selain pengadilan yang berada dalam keempat lingkungan sebagaimana diatur dalam Undang-Undang Kekuasaan Kehakiman tersebut, terdapat pula sistem penyelesaian sengketa berdasarkan yurisdiksi khusus (specific jurisdiction) yang diatur dalam berbagai peraturan perundang-undangan (Harahap, 2007: 183). Misalnya seperti pengadilan pajak, pengadilan tindak pidana korupsi, dan pengadilan hubungan industrial.

Pembedaan macam-macam lingkup dan jenis pengadilan tersebut menimbulkan implikasi tersendiri. Pembedaan terhadap lingkup dan jenis pengadilan menyebabkan adanya pembedaan kewenangan dalam proses memeriksa, mengadili, dan memutus suatu perkara. Konsekuensinya, beda lingkup pengadilannya, maka berbeda pula karakteristik jenis sengketa yang menjadi kewenangannya.

Perbedaan-perbedaan menimbulkan permasalahan kekuasaan mengadili, yang disebut dengan yurisdiksi (jurisdiction) atau kompetensi atau kewenangan mengadili (Harahap, 2007: 179), yaitu pengadilan yang berwenang mengadili sengketa tertentu sesuai dengan ketentuan yang digariskan peraturan perundang-undangan (Ingman, 1996: 1). Tujuan utama membahas yurisdiksi atau kewenangan mengadili adalah untuk memberi penjelasan mengenai masalah pengadilan mana yang benar dan tepat berwenang mengadili suatu sengketa atau kasus yang timbul, agar pengajuan dan penyampaiannya kepada pengadilan tidak keliru (Harahap, 2007: 180).

Kompetensi atau kewenangan mengadili tersebut terbagi lagi menjadi dua macam, yakni kewenangan absolut dan kewenangan relatif. Kewenangan absolut merupakan wewenang badan pengadilan dalam memeriksa jenis perkara tertentu yang secara mutlak tidak dapat diperiksa oleh badan pengadilan lain, baik dalam lingkungan peradilan yang sama, maupun dalam lingkungan peradilan lain (Mertokusumo, 2009: 86). Problematik dari kewenangan mengadili secara absolut ini digunakan untuk menjawab pertanyaan berupa peradilan macam apa yang berwenang untuk mengadili suatu perkara (Retnowulan, Sutantio \& Oeripkartawinata, 2005: 15).

Merujuk dari pertanyaan tersebut, dapat diartikan bahwa setiap jenis atau lingkup peradilan memiliki kewenangan absolut masing-masing. Kewenangan absolut tersebut akan berbeda tergantung pada jenis atau lingkup peradilannya. Pada dasarnya, kewenangan absolut tersebut ditentukan dalam suatu undang-undang (Subekti, 1977: 13). Undang-undang tersebutlah yang akan menentukan karakteristik perkara yang seperti apa yang dapat diperiksa, diadili, dan diputus oleh suatu lingkup peradilan tertentu. Di sisi lain, terdapat kewenangan mengadili yang bersifat relatif. Kewenangan ini berkaitan dengan wilayah hukum suatu pengadilan (Mertokusumo, 2009: 88). Kewenangan relatif akan menjawab 
pertanyaan peradilan wilayah manakah yang berwenang untuk mengadilisuatu perkara tertentu. Berbeda dengan kewenangan absolut yang ditentukan oleh undang-undang, kewenangan relatif ditentukan dalam hukum acara masingmasing peradilan yang bersangkutan (Subekti, 1977: 13).

\section{a. Pengadilan Negeri}

Salah satu lingkup peradilan di bawah Mahkamah Agung dalam Undang-Undang Kekuasaan Kehakiman adalah lingkup peradilan umum. Undang-Undang Peradilan Umum menentukan bahwa peradilan umum adalah salah satu pelaku kekuasaan kehakiman bagi para pencari keadilan pada umumnya mengenai perkara pidana dan perdata. Merujuk dari pengaturan dalam Undang-Undang Peradilan Umum tersebut, terlihat bahwa kewenangan mengadili yang bersifat absolut pada peradilan umum merupakan perkara pidana dan perdata pada umumnya.

Peradilan umum ini terdiri dari dua tingkat, yakni pengadilan negeri pada pemeriksaan perkara tingkat pertama dan pengadilan tinggi pada pemeriksaan perkara tingkat banding. Pengadilan negeri bertugas dan berwenang untuk memeriksa, memutus, dan menyelesaikan perkara pidana dan perdata di tingkat pertama (Mertokusumo, 2009: 83). Kewenangan absolut pengadilan negeri terletak pada tugasnya untuk mengadili perkara pidana dan perdata, namun terkhusus pada pemeriksaan perkara di tingkat pertama saja.

Kekuasaan pengadilan negeri dalam perkara perdata meliputi semua sengketa tentang hak milik atau hak-hak yang timbul karenanya, atau hakhak keperdataan lainnya, kecuali apabila dalam undang-undang ditetapkan pengadilan lain untuk memeriksa dan memutuskan (Mertokusumo, 2009: 83). Bertolak dari penjelasan tersebut, maka kewenangan absolut pengadilan negeri mengenai perkara perdata pada dasarnya untuk mengadili perkara perdata pada umumnya. Pembatasan kewenangan absolut untuk mengadili perkara atau sengketa keperdataan tersebut hanya terletak apabila dalam undang-undang lain tidak menentukan specific jurisdiction di pengadilan lain terhadap suatu perkara tertentu. Misalnya perkara perceraian bagi mereka yang beragama Islam, berdasarkan Undang-Undang Peradilan Agama menjadi kewenangan dari pengadilan agama. Oleh karena itu, sengketa yang berkaitan dengan hal tersebut sudah bukan lagi menjadi kewenangan absolut dari pengadilan negeri, meskipun perceraian tersebut merupakan salah satu bentuk dari sengketa keperdataan.

Kesimpulannya, kewenangan mengadili secara absolut pengadilan negeri terbatas pada sengketa keperdataan di tingkat pertama yang memiliki karakteristik atau kekhususan, berupa tidak dikecualikan oleh undang-undang, menjadi bagian dari kewenangan absolut pengadilan lain.

\section{b. Pengadilan Hubungan Industrial}

Pengadilan hubungan industrial merupakan salah satu bentuk sistem penyelesaian sengketa berdasarkan yurisdiksi khusus (spesific jurisdiction). Pengadilan hubungan industrial ini lahir sejak diundangkannya Undang-Undang Nomor 2 Tahun 2004 tentang Penyelesaian Perselisihan Hubungan Industrial. Pasal 1 angka 17 Undang-Undang Nomor 2 Tahun 2004 memberikan definisi mengenai pengadilan hubungan industrial sebagai pengadilan khusus yang dibentuk di lingkungan pengadilan negeri, 
yang berwenang memeriksa, mengadili, dan memberi putusan terhadap perselisihan hubungan industrial.

Merujuk dari definisi tersebut, terlihat bahwa meskipun pengadilan hubungan industrial merupakan bentuk dari specific jurisdiction, namun keberadaannya masih berada di lingkungan pengadilan negeri. Meski antara pengadilan hubungan industrial dan pengadilan negeri terdapat koneksitas, hal tersebut tidak menimbulkan hilangnya pemisahan kewenangan absolut (Harahap, 2007: 183). Mendasarkan pada definisi tersebut, pengadilan hubungan industrial memiliki kewenangan absolut untuk mengadili sengketa yang timbul akibat perselisihan hubungan industrial.

Perselisihan hubungan industrial sendiri didefinisikan dalam Pasal 1 angka 1 UndangUndang Nomor 2 Tahun 2004 sebagai perbedaan pendapat yang mengakibatkan pertentangan antara pengusaha atau gabungan pengusaha dengan pekerja/buruh atau serikat pekerja/serikat buruh karena adanya perselisihan mengenai hak, perselisihan kepentingan, perselisihan pemutusan hubungan kerja, dan perselisihan antar serikat pekerja/serikat buruh dalam satu perusahaan. Dari definisi ini dapat disimpulkan bahwa kewenangan absolut dari pengadilan hubungan industrial secara khusus untuk mengadili sengketa keperdataan antara pengusaha dengan pekerja yang berkaitan dengan hubungan kerja di antara mereka. Secara khusus Undang-Undang Nomor 2 Tahun 2004 telah menentukan siapa pihak-pihak yang berhak untuk mengajukan penyelesaiannya di pengadilan hubungan industrial. Pihak-pihak tersebut merupakan pihak-pihak yang secara khusus ada di dalam hubungan kerja, sebagaimana diatur dalam Undang-Undang Nomor 13 Tahun 2003 tentang Ketenagakerjaan.
Pasal 1 angka 15 Undang-Undang Ketenagakerjaan mendefinisikan hubungan kerja sebagai hubungan antara pengusaha dan pekerja yang didasarkan atas adanya perjanjian kerja. Ini berarti pihak-pihak dalam hubungan kerja terdiri atas pengusaha dan pekerja. Pekerja sendiri didefinisikan sebagai setiap orang yang bekerja dengan menerima upah atau imbalan dalam bentuk lain (Pasal 1 angka 3 Undang-Undang Ketenagakerjaan). Di sisi lain, pengusaha meliputi (Pasal 1 angka 5 Undang-Undang Ketenagakerjaan):

a. Orang perseorangan, persekutuan atau badan hukum yang menjalankan suatu perusahaan milik sendiri;

b. Orang perseorangan, persekutuan atau badan hukum yang secara berdiri sendiri menjalankan perusahaan yang bukan miliknya;

c. Orang perseorangan, persekutuan atau badan hukum yang berada di Indonesia mewakili perusahaan sebagaimana dimaksud dalam huruf a dan $b$ yang berkedudukan di luar wilayah Indonesia.

Selain pekerja dan pengusaha, terdapat pula organisasi pengusaha dan serikat pekerja yang diberi kemungkinan untuk mengajukan penyelesaian sengketa pada pengadilan hubungan industrial, dalam hal terjadi perselisihan hubungan industrial.

Lahirnya Undang-Undang Nomor 2 Tahun 2004 tersebut berimplikasi pada penyelesaian sengketa keperdataan yang bersumber dari hubungan kerja atau perselisihan hubungan industrial tidak lagi menjadi kewenangan absolut dari peradilan umum, khususnya pengadilan negeri. Kewenangan mengadili sengketa macam ini telah menjadi kewenangan absolut dari pengadilan hubungan industrial sebagai specific jusrisdiction . 


\section{Hubungan Direksi dengan Perusahaan}

Subjek hukum dalam hukum perdata merupakan suatu penyandang hak, yaitu manusia dan badan yang menurut hukum berwenang (bevoegdheid) menjadi pendukung hak (rechtsbevoegdheid) (Warsito, 2016:29). Manusia merupakan subjek hukum menurut konsep biologis, sebagai gejala alam, sebagai makhluk budaya ciptaan Tuhan yang dilengkapi dengan akal, perasaan, dan kehendak (Muhammad, 2014:23). Sebaliknya, badan hukum adalah subjek hukum menurut konsep yuridis, sebagai gejala hidup bermasyarakat, sebagai badan ciptaan manusia berdasar pada hukum, memiliki hak dan kewajiban seperti manusia (Muhammad, 2014: 23).

Badan hukum merupakan perkembangan dari teori subjek hukum, yang didasari karena adanya kebutuhan dari masyarakat untuk membentukbadan-badantertentuyangmenunjang kegiatan sehari-hari. Pada perkembangannya, badan-badan tersebut kemudian diberi "baju" oleh hukum, yang kemudian dapat diakui sebagai salah satu macam subjek hukum yang mempunyai kewenangan bertindak. Di dalam hukum disebut dengan artificial legal person, yang mana di mata hukum, badan-badan atau perusahaan tersebut merupakan person yang mempunyai hak dan kewajiban seperti layaknya manusia (human person) (Lewis, 2014: 46).

Menurut Otto von Gierke, badan hukum tersebut seperti manusia, yang sungguhsungguh ada di dalam pergaulan hukum (eine leibliche geistige Lebenseinheit) (Warsito, 2016: 38). Badan hukum tersebut menjadi suatu verbandspersonlichkeit, yakni suatu badan yang mewujudkan keinginannya dengan perantaraan alat-alat (organen) yang ada padanya
(Warsito, 2016: 38). Artinya, badan hukum tadi dapat mengadakan hubungan hukum dan perbuatan hukum sendiri, melalui perantaraan manusia. Badan hukum bertindak diwakili oleh pengurusnya sebagaimana ditentukan dalam anggaran dasar untuk bertindak atas nama dan untuk kepentingan badan hukum (Muhammad, 2014: 27).

Merujuk pada teori tersebut, perusahaan juga beroperasi melalui perantaraan manusia yang disebut direksi (Lewis, 2014: 54). Direksi tersebut merupakan representasi dari pikiran dan kehendak perusahaan, serta mengontrolnya (Mc Gee, Williams \& Scantan, 2005: 109). Direksi mempunyai tugas dan fungsi utama untuk menjalankan dan menjalankan pengurusan (beheer, administration or management) perusahaan (Harahap, 2015: 345). Dengan kata lain, perusahaan diurus atau dikelola oleh direksi.

Untuk dapat bertindak sebagai direksi, seseorang tersebut harus lah diangkat atau ditunjuk oleh "pemilik" perusahaan. "Pemilik" perusahaan adalah para pemegang saham dan mereka mengangkat direksi untuk menjalankan perusahaan (Lewis, 2014: 54). Pengangkatan atau penunjukan ini disebut pula sebagai pemberian amanat (legal mandatory), yang diserahkan dengan dasar konsep hubungan kepercayaan (fiduciary duties) (Kasim, 2010: 1).

Fiduciary duties tersebut terdapat dalam teori fiduciary duty yang terkait dengan kewenangan direksi dalam menjalankan perusahaan. Istilah fiduciary duty berasal dari dua kata, yakni fiducia dan duty (Fuady, 2014: 30). Fiduciary berasal dari bahasa latin fiduciarus dengan akar fidus yang berarti "kepercayaan," sedangkan duty berarti "tugas" (Fuady, 2014: 30). Dengan demikian, konsep fiduciary duty 
dapat diartikan sebagai memegang sesuatu dalam kepercayaan.

Teori atau konsep fiduciary duty ini terkait erat dengan pengangkatan direksi dan pemberian kewenangannya. Seorang direksi untuk menjalankan suatu perusahaan dibutuhkan adanya pengangkatan atau pemberian amanat oleh "pemilik" perusahaan yang merupakan pemegang saham. Pemberian amanat (legal mandatory) tersebut didasarkan atas prinsip kepercayaan sebagaimana dimaksudkan oleh teorifiduciaryduty tersebut. Dengan demikian, direksi merupakan pengelola dan pengurus dari suatu perusahaan. Artinya, kegiatan atau perbuatan hukum dari perusahaan dilakukan melalui perantaraan direksi sebagai mediumnya. Tanpa direksi, perusahaan tidak dapat beroperasi dan melakukan berbagai perbuatan hukum untuk menunjang hak dan kewajibannya. Direksi merupakan representasi dari perusahaan itu sendiri.

\section{METODE}

Penelitian hukum merupakan suatu kegiatan ilmiah yang didasarkan pada metode, sistematika dan pemikiran tertentu yang bertujuan untuk mempelajari satu atau beberapa gejala hukum tertentu, dengan jalan menganalisisnya (Soekanto, 2012: 43). Untuk itu, suatu penelitian hukum membutuhkan metode sebagai arah dan petunjuk penelitian. Metode yang digunakan dalam penelitian ini merupakan metode penelitian hukum yang bersifat normatif. Normatif artinya melakukan penelitian hukum dengan cara meneliti bahan pustaka atau data sekunder, yang terdiri dari bahan hukum primer, sekunder, dan tersier (Soekanto \& Mamudji, 2011: 14).

Data yang diperoleh dari penelitian, selanjutnya dianalisis secara kualitatif.
Kualitatif artinya analisis dilakukan dengan menggambarkan, menjelaskan serta menganalisis data yang diperoleh selama penelitian berdasarkan bahan-bahan hukum yang secara sistemik dan akurat (Soekanto, 2012: 32). Data yang telah dianalisis kemudian hasilnya dipaparkan secara deskriptif.

\section{HASIL DAN PEMBAHASAN}

Putusan Nomor $521 \mathrm{PK} / \mathrm{Pdt} / 2017$ bermula dari adanya pengajuan gugatan ke pengadilan negeri oleh seorang mantan direksi di Bank Pembangunan Daerah DIY. Direksi tersebut menjabat sejak dikeluarkannya Surat Keputusan Gubernur DIY Nomor 49 Tahun 2003 tertanggal 12 April 2003. Masa jabatan direksinya diakhiri pada tahun 2009 dengan dikeluarkannya Keputusan Gubernur DIY Nomor 162/KEP/2009 tertanggal 4 September 2009.

Atas jabatannya sebagai direksi, apabila mendasarkan pada Keputusan Gubernur DIY Nomor 103 Tahun 2000 tentang Penghasilan, Hak-Hak, dan Penghargaan Direksi Bank Pembangunan Daerah DIY, direksi tersebut berhak atas uang jasa dan pengabdian setiap bulannya. Uang jasa dan pengabdian ini sejak bulan April 2007 sampai dengan September 2009 tidak dibayarkan, hingga akhirnya direksi tersebut mengajukan gugatan ke Pengadilan Negeri Yogyakarta pada tahun 2011 melawan perusahaannya, yakni Bank Pembangunan Daerah DIY.

Perkara a quo telah diputus di tingkat peninjauan kembali dengan Putusan Nomor 521 PK/Pdt/2017 pada tanggal 25 Januari 2018. Pada putusan peninjauan kembali tersebut, Mahkamah Agung menolak permohonan peninjauan kembali yang diajukan oleh direksi. Mencermati 
pada bagian pertimbangan di dalam putusan, Mahkamah Agung menyebutkan bahwa pokok sengketa dalam perkara a quo merupakan bagian dari kewenangan absolut pengadilan hubungan industrial, sehingga peradilan umum, dalam hal ini Pengadilan Negeri Yogyakarta tidak berwenang untuk memeriksa dan mengadili perkara a quo (halaman 28 Putusan $521 \mathrm{PK} / \mathrm{Pdt} / 2017$ ).

Berarti terdapat perbedaan pendapat antara direksi tersebut dengan Mahkamah Agung. Direksi tersebut berpendapat bahwa perkaranya merupakan sengketa keperdataan pada umumnya, sehingga merupakan bagian dari kewenangan absolut pengadilan negeri. Di sisi lain, Mahkamah Agung mengemukakan bahwa pokok perkara tersebut merupakan sengketa yang berkaitan dengan hubungan kerja, sehingga merupakan bagian dari kewenangan pengadilan hubungan industrial. Bertitik tolak pada perbedaan kedua pihak ini, menjadi pertanyaan, sebenarnya sengketa tersebut menjadi kewenangan pengadilan mana?

Mendasarkan pada pertimbangan yang dituangkan Mahkamah Agung dalam Putusan Nomor $521 \mathrm{PK} / \mathrm{Pdt} / 2017$, pokok sengketa antara direksi dengan perusahaannya, yakni Bank Pembangunan Daerah DIY, merupakan bagian dari kewenangan absolut pengadilan hubungan industrial. Pengaturan mengenai karakteristik perkara yang menjadi kewenangan absolut dari pengadilan hubungan industrial terdapat dalam Undang-Undang Nomor 2 Tahun 2004 tentang Penyelesaian Perselisihan Hubungan Industrial.

Pasal 1 angka 17 Undang-Undang Nomor 2 Tahun 2004 mengatur bahwa pengadilan hubungan industrial merupakan pengadilan khusus yang dibentuk di lingkungan pengadilan negeri yang berwenang memeriksa, mengadili, dan memberi putusan terhadap perselisihan hubungan industrial. Pasal tersebut menetapkan kewenangan absolut dari pengadilan hubungan industrial, yakni sengketa-sengketa yang mempunyai karakteristik sebagai sengketa perselisihan hubungan industrial. Artinya, kewenangan absolut pengadilan hubungan industrial hanya terbatas pada sengketa yang bersumber dari perselisihan hubungan industrial.

Untuk mengetahui secara pasti mengenai kewenangan absolut pengadilan hubungan industrial, maka perlu merujuk kepada pengertian perselisihan hubungan industrial. Definisi tersebut terdapat dalam Pasal 1 angka 1 Undang-Undang Nomor 2 Tahun 2004, perselisihan hubungan industrial diartikan sebagai perbedaan pendapat yang mengakibatkan pertentangan antara pengusaha atau gabungan pengusaha dengan pekerja/buruh atau serikat pekerja/serikat buruh karena adanya perselisihan hak, perselisihan kepentingan, perselisihan pemutusan hubungan kerja, dan perselisihan antar serikat pekerja/ serikat buruh dalam satu perusahaan.

Mengacu pada definisi tersebut, perselisihan hubungan industrial terbatas pada pihak-pihak tertentu saja, yakni perselisihan antara pengusaha atau gabungannya dengan pekerja atau serikatnya. Secara singkat, hanya ada dua pihak dalam suatu perselisihan hubungan industrial, yakni pengusaha dan pekerja. Perselisihan hubungan industrial merupakan perbedaan pendapat antara pengusaha dengan pekerja. Artinya, kewenangan absolut dari pengadilan hubungan industrial pada intinya adalah memeriksa, mengadili, dan memutus perkara yang berasal dari perselisihan dalam hubungan antara pengusaha dengan pekerja. Hubungan antara pengusaha dengan pekerja tersebut disebut sebagai hubungan kerja. Definisi hubungan kerja dapat ditemukan dalam 
Pasal 1 angka 15 Undang-Undang Nomor 13 Tahun 2003 tentang Ketenagakerjaan, yakni hubungan antara pengusaha dengan pekerja berdasarkan perjanjian kerja.

Mahkamah Agung berpendapat bahwa sengketa antara direksi dengan perusahaannya tersebut merupakan kewenangan absolut dari pengadilan hubungan industrial. Artinya, Mahkamah Agung berpandangan bahwa sengketa tersebut merupakan perselisihan hubungan industrial antara pengusaha dengan pekerja dalam hubungan kerja. Direksi dianggap sebagai pekerja, dan Bank Pembangunan Daerah DIY merupakan pengusahanya. Lantas, apakah direksi memang dapat dikategorikan sebagai pekerja?

Definisi pekerja diatur dalam Pasal 1 angka 3 Undang-Undang Ketenagakerjaan. Pekerja/ buruh diartikan sebagai setiap orang yang bekerja dengan menerima upah atau imbalan dalam bentuk lain. Mengacu pada definisi tersebut, direksi tersebut memang merupakan seseorang yang bekerja dengan menerima upah atau imbalan dalam bentuk lain. Direksi tersebut bekerja di perusahaannya, yakni Bank Pembangunan Daerah DIY, yang kemudian timbul upah atau imbalan dalam bentuk lain atas pekerjaannya tersebut. Artinya, apabila memenuhi definisi ini, maka sengketa tersebut benar merupakan kewenangan absolut dari pengadilan hubungan industrial, karena merupakan sengketa antara pengusaha dengan pekerjanya. Direksi sebagai pekerjanya, sementara Bank Pembangunan Daerah DIY sebagai pengusahanya.

Dilihat dari sisi lain, Undang-Undang Ketenagakerjaan juga memberikan definisi pengusaha. Pasal 1 angka 5 menetapkan karakteristik seseorang yang dapat disebut sebagai pengusaha, yakni: a. Orang perseorangan, persekutuan atau badan hukum yang menjalankan suatu perusahaan milik sendiri;

b. Orang perseorangan, persekutuan atau badan hukum yang secara berdiri sendiri menjalankan perusahaan yang bukan miliknya;

c. Orang perseorangan, persekutuan atau badan hukum yang berada di Indonesia mewakili perusahaan sebagaimana dimaksud dalam huruf a dan $b$ di atas, yang berkedudukan di luar wilayah Indonesia.

Menelaah lebih jauh melalui definisi pengusaha dalam Pasal 1 angka 5 UndangUndang Ketenagakerjaan tersebut, menjadi timbul pertanyaan, apakah direksi dapat pula dikategorikan sebagai pengusaha? Bila iya, lalu apakah posisi direksi dalam perusahaan lebih tepat disebut sebagai pekerja atau sebagai pengusaha? Dua hal ini akan menimbulkan implikasi yang berbeda. Ketika direksi tersebut lebih tepat dipandang sebagai pekerja, maka penafsiran Mahkamah Agung bahwa pokok sengketa a quo adalah kewenangan absolut pengadilan hubungan industrial ialah tepat pula. Sebaliknya, apabila direksi lebih tepat diposisikan sebagai pengusaha, maka penafsiran Mahkamah Agung tersebut tidak tepat, sehingga pokok sengketa antara direksi dengan Bank Pembangunan Daerah DIY sebenarnya adalah sengketa keperdataan biasa yang menjadi kewenangan absolut pengadilan negeri.

Untuk dapat mengetahui secara pasti mengenai posisi direksi dalam perusahaan, kiranya perlu untuk meninjau teori-teori dalam hukum perusahaan. Perusahaan merupakan salah satu bentuk badan yang dapat diakui sebagai subjek hukum dalam hukum perdata. Hal ini dikarenakan perusahaan diberikan "baju" oleh hukum untuk dapat menyandang hak dan kewajiban seperti layaknya manusia. Perusahaan 
merupakan artificial legal person atau badan hukum buatan, yang berarti perusahaan adalah person yang mempunyai hak dan kewajiban seperti layaknya manusia (human person) (Lewis, 2014: 46).

Meski suatu perusahaan diakui secara yuridis sebagai subjek hukum, namun terdapat permasalahan. Bentuknya yang merupakan fictie hukum menyebabkan perusahaan tidak dapat bertindak dan melakukan perbuatan hukum sendiri. Sebagaimana dikemukakan oleh Woon (1998: 47):

a company has nobody to be kicked, and no soul to be damned, no hands with which to work and no mind with which to think. It cannot act by itself. It must work through the medium of some human being.

Singkatnya, perusahaan sebagai subjek hukum artifisial, tidak dapat dilihat dan diraba (invicible and intangible), tetapi eksistensinya riil (Harahap, 2015: 37). Untuk melaksanakan hak dan kewajibannya, serta melakukan perbuatan hukum, perusahaan memerlukan medium atau perantara. Perantara tersebut merupakan pengurus yang ditunjuk atau diberi kewenangan untuk itu. Pada perusahaan, pengurus tersebut disebut dengan direksi (Harahap, 2015: 59).

Tugas dan fungsi utama direksi adalah menjalankan dan melaksanakan pengurusan perusahaan (beheer, administration or management) (Harahap, 2015: 345). Akibat tugasnya yang melakukan pengoperasian dan manajemen perusahaan, direksi dapat pula disebut sebagai personifikasi perusahaan itu sendiri (Pramono, 2007: 15). Direksi yang membuat suatu perusahaan berjalan, kemudian mengurusnya dan bertanggung jawab atas perbuatan pengurusannya itu. Di sisi lain, direksi juga diberikan kewenangan untuk mewakili perusahaan baik di dalam maupun di luar perusahaan, di dalam maupun di luar pengadilan (Harahap, 2015: 349). Kewenangan direksi yang sedemikian rupa dilakukan untuk dan atas nama perusahaan sebagai bagian dari tindakan pengurusannya tersebut. Dengan kata lain, direksi merupakan representasi dari perusahaan.

Kewenangan-kewenangan direksi tersebut berasal dari "pemilik" perusahaan yang merupakan para pemegang saham (Lewis, 2014: 54). Para pemegang saham tersebut mengangkat direksi untuk menjalankan perusahaan dan melakukan tindakan pengurusan untuk dan atas nama perusahaan. Induk dari pemberian kewenangan ini adalah volmacht, sehingga sifat hubungan hukum direksi dengan perusahaannya merupakan hubungan hukum perwakilan, yang secara spesifik mengambil jenis perwakilan yang dikenal dalam surseance van betaling, yang disebut bewindvoering (Pramono, 2007: 16). Kewenangan direksi untuk mengurus dan memelihara perusahaan disebut dengan tindakan beheer en beschikking daden (Pramono, 2007:16).

Berkaca dari tugas dan wewenang direksi di atas, terlihat bahwa kehadiran direksi dalam perusahaan merupakan sesuatu yang sangat penting. Keberadaan direksi dalam suatu perusahaan merupakan suatu keharusan, dengan kata lain perusahaan wajib memiliki direksi (Raffles, 2010: 68). Perusahaan sebagai artificial person tidak dapat berbuat apa-apa tanpa adanya bantuan dari direksi sebagai natural person (Widjaya, 2000: 56).

Menurut teori organisme, direksi adalah organ atau alat kelengkapan perusahaan, seperti halnya manusia mempunyai organ-organ, dan setiap gerakan organ-organ itu dikehendaki atau diperintahkan oleh otak manusia (Pramono, 2007: 
15). Pada konteks perusahaan, kehadiran direksi sebagai bagian dari perusahaan merupakan hal yang penting. Direksi ibarat nyawa bagi perusahaan (Kusumawardani, 2013: 10).

Mendasarkan pada teori-teori tersebut, direksi merupakan bagian dari perusahaan yang mempunyai tugas dan fungsi utama untuk menjalankan dan melakukan perbuatan pengurusan perusahaan. Direksi merupakan representasi sekaligus personifikasi dari perusahaan. Melihat dari tugas dan fungsi direksi sebagaimana dikenal dalam hukum perusahaan, maka sebenarnya posisi direksi apakah dapat disebut sebagai pengusaha sebagaimana dimaksud dalam Pasal 1 angka 5 Undang-Undang Ketenagakerjaan?

Ditelaah kembali bahwa pengertian pengusaha sebagaimana didefinisikan oleh Undang-Undang Ketenagakerjaan meliputi:

1. Orang perseorangan, persekutuan atau badan hukum yang menjalankan suatu perusahaan milik sendiri;

2. Orang perseorangan, persekutuan atau badan hukum yang secara berdiri sendiri menjalankan perusahaan yang bukan miliknya;

3. Orang perseorangan, persekutuan atau badan hukum yang berada di Indonesia mewakili perusahaan sebagaimana dimaksud dalam butir 1 dan 2 di atas, yang berkedudukan di luar wilayah Indonesia.

Jika dalam teori-teori hukum perusahaan, direksi mempunyai fungsi sebagai pihak yang menjalankan dan melakukan kegiatan pengurusan perusahaan, maka direksi tersebut dapat diartikan pula sebagai pengusaha yang dimaksud oleh Undang-Undang Ketenagakerjaan. Pasal 1 angka
5 hurufb menyebutkan bahwa salah satu indikator suatu pihak bisa disebut sebagai pengusaha yakni bila orang perseorangan, persekutuan atau badan hukum yang secara berdiri sendiri tersebut menjalankan perusahaan yang bukan miliknya. Direksi merupakan pihak yang mempunyai fungsi untuk menjalankan perusahaan, dengan demikian direksi tersebut merupakan pengusaha. Meski direksi menjalankan perusahaan yang bukan miliknya, yakni "milik" pemegang saham, Undang-Undang Ketenagakerjaan tetap memosisikan direksi tersebut sebagai pengusaha.

Apabila mengacu pada pembahasan tersebut, maka pada perkara a quo, sejatinya kedudukan direksi tersebut lebih tepat dipandang sebagai pengusaha, bukan pekerja. Jika direksi tersebut bukanlah pekerja, maka sengketa antara direksi tersebut dengan perusahaannya, Bank Pembangunan Daerah DIY bukanlah sengketa perselisihan hubungan industrial antara pekerja dengan pengusaha yang timbul dari hubungan kerja. Apabila bukan termasuk perselisihan hubungan industrial, maka perkara a quo bukanlah termasuk sebagai kewenangan absolut dari pengadilan hubungan industrial sebagaimana dikemukakan Mahkamah Agung dalam putusannya. Pengadilan hubungan industrial tidaklah berwenang untuk mengadili perkara a quo.

Menganalisis lebih spesifik lagi, pihak yang digugat oleh direksi tersebut adalah perusahaan tempat direksi tersebut menjabat, yakni Bank Pembangunan Daerah DIY. Berpedoman pada Permendagri Nomor 1 Tahun 1998 tentang Bentuk Hukum Bank Pembangunan Daerah, dalam Pasal 2 ditetapkan bahwa bentuk hukum Bank Pembangunan Daerah dapat berupa perusahaan daerah atau perseroan terbatas. Saat ini, bentuk hukum Bank Pembangunan Daerah 
DIY ialah perseroan terbatas sebagaimana ditetapkan dalam Perda DIY Nomor 11 Tahun 2012 tentang Perubahan Bentuk Badan Hukum Bank Pembangunan Daerah Provinsi DIY menjadi Perseroan Terbatas Bank Pembangunan Daerah DIY. Sebelum tahun 2012, bentuk hukum Bank Pembangunan Daerah DIY masih berupa perusahaan daerah.

Padaperkara $a q u o$, direksiyangbersangkutan menjabat mulai dari tahun 2003 hingga tahun 2009 (halaman 2-3 Putusan Nomor 521 PK/Pdt/2017). Artinya, pada saat direksi tersebut menjabat, bentuk hukum Bank Pembangunan Daerah DIY masih merupakan perusahaan daerah.

Pengaturan mengenai perusahaan daerah termaktub dalam Undang-Undang Nomor 5 Tahun 1962 tentang Perusahaan Daerah. Pada Pasal 11 ayat (1) dicantumkan bahwa suatu perusahaan daerah dipimpin oleh direksi. Tugas dan fungsi direksi dalam perusahaan daerah diatur dalam Pasal 14 dan 15 UndangUndang Perusahaan Daerah. Direksi suatu perusahaan daerah mempunyai kewenangan untuk mewakili perusahaan daerah di dalam dan di luar pengadilan. Selain itu, direksi juga bertugas untuk menentukan kebijaksanaan dalam pimpinan perusahaan daerah, serta mengurus dan menguasai kekayaan perusahaan daerah.

Sejalan dengan teori-teori mengenai direksi dalam hukum perusahaan, UndangUndang Perusahaan Daerah juga memberikan kewenangan yang sama bagi direksinya untuk melakukan perbuatan pengurusan dan kegiatan operasional perusahaan daerah. Artinya, pada Bank Pembangunan Daerah DIY tersebut, yang mempunyai kewenangan untuk menjalankan perusahaan ialah direksinya. Dengan kata lain, direksi yang bersangkutan ialah pihak yang diberi kewenangan oleh Undang-Undang Perusahaan Daerah untuk memimpin, menjalankan, dan mengurus kegiatan Bank Pembangunan Daerah DIY.

Dikaitkan dengan definisi pengusaha dalam Undang-Undang Ketenagakerjaan yang menetapkan bahwa pihak yang menjalankan suatu perusahaan adalah pengusaha, maka direksi tersebut tetaplah dapat disebut sebagai pengusaha. Direksi tersebut yang menjalankan perusahaan, dalam hal ini Bank Pembangunan Daerah DIY, sehingga dapat disebut sebagai pengusaha. Pengaturan dalam Undang-Undang Perusahaan Daerah ini sejalan dengan istilah pengusaha dalam Undang-Undang Ketenagakerjaan.

Ketentuan lain yang mengatur terkait Bank Pembangunan Daerah ini terdapat dalam Undang-Undang Nomor 13 Tahun 1962 tentang Ketentuan-Ketentuan Pokok Bank Pembangunan Daerah. Pasal 11 ayat (1) Undang-Undang Nomor 13 Tahun 1962 mengatur bahwa Bank Pembangunan Daerah sehari-hari dipimpin oleh direksi. Undang-Undang Nomor 13 Tahun 1962 kembali menegaskan bahwa direksi ialah bagian penting dari Bank Pembangunan Daerah yang berwenang untuk memimpin bank.

Sejalan dengan Undang-Undang Perusahaan Daerah, Undang-Undang Nomor 13 Tahun 1962 pada Pasal 14 dan 15 juga memberi perincian perihal tugas dan fungsi direksi bank. Direksi Bank Pembangunan Daerah mempunyai tugas dan fungsi untuk mengurus dan menguasai harta kekayaan bank, melakukan kebijaksanaan bank sehari-hari, serta mewakili bank di dalam dan di luar pengadilan.

Isi dari ketentuan yang ada dalam UndangUndang Nomor 13 Tahun 1962 terkait direksi tersebut juga masih sejalan dengan teori-teori 
hukum perusahaan yang telah dijabarkan sebelumnya. Undang-undang tersebut secara eksplisit mengatur mengenai kewenangan direksi sebagai pemimpin dan pengurus perusahaan. Jalannya kegiatan di Bank Pembangunan Daerah ditentukan oleh direksinya. Hal ini tentunya menguatkan interpretasi posisi direksi di Bank Pembangunan Daerah ialah sebagai pengusaha, bukan pekerja, sebagaimana diatur oleh UndangUndang Ketenagakerjaan.

Aturan pelaksanaan dari Undang-Undang Nomor 5 Tahun 1962 dan Undang-Undang Nomor 13 Tahun 1962 salah satunya adalah Permendagri Nomor 58 Tahun 1999 tentang Direksi dan Dewan Pengawas Bank Pembangunan Daerah. Permendagriinisecarakhusus mengatur mengenai jabatan direksi di Bank Pembangunan Daerah. Ditegaskan kembali dalam Pasal 10 Permendagri tersebut, bahwa direksi Bank Pembangunan Daerah mempunyai tugas untuk memimpin, mengurus, dan melaksanakan kebijakan umum bank sesuai dengan visi dan misi bank.

Merinci dari Pasal 10 tersebut, Pasal 11 Permendagri tersebut mencantumkan tugas dan wewenang direksi Bank Pembangunan Daerah secara jelas, yakni:

1. Menetapkan kebijaksanaan pengurusan dan pengelolaan bank;

2. Mengurus dan menguasai kekayaan bank sesuai dengan ketentuan peraturan perundang-undangan yang berlaku;

3. Menyusun dan menyampaikan laporan keuangan dan tahunan bank sesuai ketentuan peraturan perundang-undangan yang berlaku;

4. Menyusun neraca dan perhitungan laba/rugi tahunan bank;

5. Menyampaikan realisasi rencana kerja dan anggaran bank;

6. Mengangkat dan memberhentikan pegawai sesuai dengan ketentuan bank;

7. Mengadakan kerjasama dengan pihak lain sesuai dengan ketentuan bank;

8. Mewakili bank di dalam dan di luar pengadilan.

Berdasarkan pada kedua pasal di atas, Permendagri Direksi Bank Pembangungan Daerah ini juga menetapkan tugas, fungsi, dan kewenangan direksi. Secara umum, dapat disimpulkan bahwa memang direksi Bank Pembangunan Daerah mempunyai posisi sebagai pemimpin dan pengurus perusahaan. Jalannya kegiatan Bank Pembangunan Daerah tergantung dari direksi sebagai pemimpinnya. Melihat ketentuan Pasal 10 dan Pasal 11 Permendagri tersebut terlihat bahwa keberadaan direksi sangatlah penting dalam Bank Pembangunan Daerah. Oleh karena itu, senada dengan pembahasan-pembahasan sebelumnya, Pasal 10 dan Pasal 11 Permendagri tersebut menguatkan tafsiran posisi direksi dalam Bank Pembangunan Daerah ialah sebagai pengusaha sebagaimana diatur dalam Undang-Undang Ketenagakerjaan. Direksi Bank Pembangunan Daerah merupakan pihak yang menjalankan perusahaan, sehingga disebut sebagai pengusaha. Artinya, bila direksi adalah pengusaha, bukan pekerja, maka hubungan direksi dengan Bank Pembangunan Daerah DIY sebagai perusahaannya tersebut bukanlah hubungan kerja.

Pasal 4 ayat (2) Permendagri tersebut juga mengatur mengenai mekanisme pengangkatan direksi di Bank Pembangunan Daerah. Direksi diangkat dan dipilih oleh gubernur atas usul Rapat Umum Pemegang Saham untuk masa jabatan empat tahun. Pengangkatan direksi yang sedemikian rupa oleh gubernur dan pemegang 
saham merupakan pemberian amanat atau legal mandatory (Kasim, 2010: 1). Artinya, direksi merupakan pihak yang berkedudukan sebagai pemegang amanat yang bertanggung jawab penuh atas pengurusan perusahaan (Hidayatullah \& Sulistiowati, 2017: 81). Keadaan yang sedemikian rupa ini terkait dengan teori wewenang, yang mana kekuasaan legal seseorang didapatkan dari pemberian wewenang, sehingga pemberian wewenang direksi dari "pemilik" perusahaan merupakan dasar untuk bertindak, berbuat dan melakukan kegiatan atau aktivitas dalam perusahaan (Kusumawardani, 2013: 12).

Hukum perusahaan pun mengenal adanya teori fiduciary duty. Teori ini terkait dengan kewenangan direksi dalam menjalankan perusahaan. Istilah fiduciary duty berasal dari dua kata, yakni fiducia dan duty (Fuady, 2014: 30). Fiduciary berasal dari bahasa latin fiduciarus dengan akar fidus yang berarti "kepercayaan," sedangan duty berarti "tugas" (Fuady, 2014: 30). Dengan demikian, konsep fiduciary duty dapat diartikan sebagai memegang sesuatu dalam kepercayaan.

Teori atau konsep fiduciary duty ini terkait erat dengan pengangkatan direksi dan pemberian kewenangannya. Seorang direksi untuk menjalankan suatu perusahaan dibutuhkan adanya pengangkatan atau pemberian amanat oleh "pemilik" perusahaan yang merupakan pemegang saham. Pemberian amanat (legal mandatory) tersebut didasarkan atas prinsip kepercayaan sebagaimana dimaksudkan oleh teori fiduciary duty tersebut.

Adanya hubungan yang sedemikian rupa, menjadikan hubungan hukum antara direksi dengan Rapat Umum Pemegang Saham atau dengan perusahaannya merupakan hubungan yang bersifat kepercayaan (fiduciary duties) dan pemberian amanat (legal mandatory) (Kasim, 2010: 1). Hubungan yang demikian itu merupakan hubungan dalam hukum korporasi atau hukum perusahaan. Berbeda dengan hubungan hukum antara pengusaha dan pekerja, hubungan tersebut dinamakan dengan hubungan kerja. Hubungan kerja timbul karena didasari adanya suatu perjanjian kerja. Dengan kata lain, dalam hubungan tersebut terdapat hubungan atasanbawahan (dients verhouding) atau hubungan yang bersifat subordinasi (Kasim, 2010: 1). Sedangkan pada direksi tersebut, hubungannya berada dalam ranah hukum perusahaan, yang mana tidak terdapat hubungan atasan-bawahan sebagaimana terdapat dalam hubungan kerja antara pengusaha dan pekerja. Hubungan tersebut lebih condong kepada hubungan koordinasi (partnership) (Kasim, 2010: 1).

Keadaan yang demikian ini menjadikan posisi direksi di perusahaan merupakan seorang pengusaha sebagaimana dimaksud dalam Pasal 1 angka 5 hurufbUndang-UndangKetenagakerjaan. Antara direksi dengan perusahaannya tidak ada perjanjian kerja, sehingga tidak timbul lah suatu hubungan kerja. Oleh karena itu, posisi direksi di Bank Pembangunan Daerah lebih tepat disebut sebagai pengusaha ketimbang pekerja. Jika dikaitkan dengan tugas, fungsi, dan wewenang direksi untuk memelihara dan mengurus perusahaan, pemberian wewenang atau amanat kepada direksi tersebut tentunya juga termasuk untuk mengangkat dan memberhentikan pekerja yang bekerja di perusahaan tersebut (Pramono, 2007: 17).

Direksi merupakan representasi dari perusahaan, sehingga bertindak sebagai pengusaha dalam perjanjian kerja yang dibuat untuk mengikat pekerja dalam hubungan kerja. 
Apabila di perusahaan direksi dipandang mempunyai posisi sebagai pekerja, maka pelaksanaan wewenang yang demikian ini tidaklah mungkin dapat dilaksanakan direksi dalam menjalankan perusahaan.

Permendagri Nomor 58 Tahun 1999 tentang Direksi dan Dewan Pengawas Bank Pembangunan Daerah pada Pasal 11 angka 6 juga secara tegas menetapkan salah satu kewenangan direksi Bank Pembangunan Daerah, yakni untuk mengangkat dan memberhentikan pekerja Bank Pembangunan Daerah. Adanya ketentuan ini semakin menegaskan posisi direksi di dalam Bank Pembangunan Daerah yakni sebagai pengusaha, bukanlah sebagai pekerja. Wewenang pengangkatan dan pemberhentian pekerja hanyalah dapat dilakukan oleh pihak yang berposisi sebagai pengusaha. Tidaklah mungkin di dalam hubungan kerja pihaknya hanya pekerja dan pekerja saja, selalu ada pengusaha. Direksi bertindak atas nama pengusaha sebagai pihak dalam perjanjian kerja dengan pekerja.

Berdasarkan hal-hal yang telah diuraikan di atas, posisi direksi di perusahaan ialah sebagai pengusaha sebagaimana diatur dalam Pasal 1 angka 5 huruf b Undang-Undang Nomor 13 Tahun 2003 tentang Ketenagakerjaan. Direksi di dalam perusahaan mempunyai tugas, fungsi, dan kewenangan untuk menjalankan perusahaan dan bertindak mewakili perusahaan sebagai pengusaha dalam perjanjian kerja. Wewenang yang sedemikian rupa memenuhi kriteria Pasal 1 angka 5 huruf $b$ tersebut, yakni yang disebut pengusaha ialah termasuk orang perseorangan, persekutuan atau badan hukum yang secara berdiri sendiri menjalankan perusahaan yang bukan miliknya. Direksi pada perkara a quo berdasarkan pembahasan di atas lebih tepat diposisikan sebagai pengusaha di Bank
Pembangunan Daerah DIY tersebut.

Akibatnya, dengan posisi pengusaha yang diduduki oleh direksi tersebut, maka hubungan antara direksi dengan Bank Pembangunan Daerah DIY bukanlah hubungan kerja sebagaimana dimaksudkan dalam Undang-Undang Ketenagakerjaan. Hubungan tersebut bukanlah hubungan antara pengusaha dengan pekerja, sehingga sengketa yang terjadi antara keduanya bukanlah termasuk sengketa akibat adanya perselisihan hubungan industrial sebagaimana diatur dalam Undang-Undang Nomor 2 Tahun 2004 tentang Penyelesaian Perselisihan Hubungan Industrial.

Perselisihan hubungan industrial dalam Undang-Undang Nomor 2 Tahun 2004 dalam Pasal 1 angka 1 diartikan sebagai perselisihan atau perbedaan pendapat yang terjadi antara pengusaha dan pekerja. Pihak-pihak dalam perselisihan hubungan industrial telah dikhususkan dalam undang-undang hanya meliputi pengusaha dan pekerja. Oleh karena direksi tersebut bukanlah seorang pekerja dalam hubungan kerja, maka sengketa tersebut bukanlah termasuk kategori perselisihan hubungan industrial.

Mendasarkan pada hal tersebut, perkara a quo yang merupakan sengketa antara direksi dengan Bank Pembangunan Daerah DIY dalam Putusan Nomor 521 PK/Pdt/2017 bukanlah merupakan kewenangan mengadili yang bersifat absolut dari pengadilan hubungan industrial sebagaimana dikemukakan oleh Mahkamah Agung dalam pertimbangannya. Perselisihan antara keduanya bukanlah termasuk perselisihan hubungan industrial, sehingga jika mendasarkan pada ketentuan Pasal 1 angka 17 Undang-Undang Nomor 2 Tahun 2004, perselisihan tersebut bukan menjadi kewenangan absolut pengadilan 
hubungan industrial. Pasal 1 angka 17 secara tegas telah menetapkan kewenangan absolut dari pengadilan hubungan industrial adalah hanya untuk memeriksa, mengadili, dan memutus perselisihan hubungan industrial saja.

Perkara antara direksi melawan perusahaannya, Bank Pembangunan Daerah DIY, mengenai tuntutan pembayaran uang jasa dan pengabdian pada Putusan Nomor $521 \mathrm{PK} /$ Pdt/2017 bukanlah menjadi kewenangan absolut pengadilan hubungan industrial karena tidak termasuk sebagai kategori perselisihan hubungan industrial. Sengketa antara kedua belah pihak tersebut merupakan sengketa keperdataan biasa, dan untuk itu, semestinya menjadi kewenangan absolut dari pengadilan negeri, yang bertugas dan berwenang untuk memeriksa, memutus, dan menyelesaikan perkara pidana dan perdata pada umumnya.

\section{KESIMPULAN}

Pengadilan hubungan industrial tidak memiliki kewenangan untuk memeriksa, mengadili, dan memutus perkara gugatan uang jasa dan pengabdian antara direksi melawan perusahaannya, Bank Pembangunan Daerah DIY, sebagaimana dikemukakan oleh Mahkamah Agung dalam Putusan Nomor 521 PK/Pdt/2017, karena perkara a quo bukan merupakan perkara mengenai perselisihan hubungan industrial.

Posisi direksi di perusahaannya bukan sebagai pekerja, melainkan sebagai pengusaha sebagaimana dimaksud dalam Pasal 1 angka 5 huruf b Undang-Undang Nomor 13 Tahun 2003 tentang Ketenagakerjaan. Konsekuensinya, hubungan antara direksi dengan perusahaannya bukanlah hubungan kerja, sehingga sengketa antara keduanya bukanlah suatu perselisihan hubungan industrial yang menurut UndangUndang Nomor 2 Tahun 2004 mensyaratkan para pihaknya hanyalah antara pengusaha dengan pekerja saja. Dikarenakan sengketa di antara keduanya bukan merupakan perselisihan hubungan industrial, maka perkara a quo bukanlah menjadi kewenangan mengadili secara absolut dari pengadilan hubungan industrial. Perkara $a$ quo merupakan sengketa keperdataan biasa yang menjadi kewenangan absolut pengadilan negeri.

\section{SARAN}

Berkaca dari apa yang telah ditemukan atas pembahasan Putusan Peninjauan Kembali Mahkamah Agung tersebut, hendaknya hakim dalam memeriksa perkara harus lebih jeli untuk melakukan analisis dan interpretasi terhadap peraturan perundang-undangan serta teoriteori dalam ilmu hukum yang berkaitan dengan perkara.

Hukum adalah suatu sistem, yang mana antara satu dengan yang lainnya saling terkait satu sama lain dan saling berhubungan satu sama lain. Dalam proses berpikir, menggali, dan menemukan hukum untuk memutus perkara hendaknya hakim harus memperhatikan dan mempelajari berbagai sisi dari pembagianpembagian hukum yang ada. Sebagaimana yang ada dalam perkara ini, tidak bisa hanya dilihat dari satu bagian hukum saja, yakni misalnya dari kaidah-kaidah serta teori yang berkaitan dengan hukum ketenagakerjaan saja, tapi juga harus memperhatikan pula kaidah-kaidah dan teori dari hukum perdata, hukum acara, serta hukum perusahaan. Dengan pendekatan yang berbeda, yang lebih sistematis dan menyeluruh, ternyata mengarah pada kesimpulan yang berbeda, sehingga putusannya pun bisa berbeda pula. 


\section{DAFTAR ACUAN}

Butarbutar, E.N. (2009, Juni). Konsep keadilan dalam sistem peradilan perdata. Mimbar Hukum, 21(2), 355-369.

Fuady, M. (2014). Doktrin-doktrin modern dalam corporate law \& eksistensinya dalam hukum Indonesia. Bandung: Citra Aditya Bakti.

Harahap, M.Y. (2015). Hukum perseroan terbatas. Jakarta: Sinar Grafika.

(2007). Hukum acara perdata. Jakarta: Sinar Grafika.

Hidayatullah \& Sulistiowati. (2017). Kedudukan pekerja yang diangkat menjadi anggota direksi tanpa adanya pengakhiran hubungan kerja pada PT National Utility Helicopter (Studi kasus putusan Pengadilan Hubungan Industrial nomor 195/PHI.G/2009/JKT.PST juncto putusan Mahkamah Agung nomor 197 K/PDT. SUS/2010). Yogyakarta: Universitas Gadjah Mada.

Husni, L. (2004). Penyelesaian perselisihan hubungan industrial melalui pengadilan \& di luar pengadilan. Jakarta: PT Raja Grafindo Persada.

Ingman, T. (1996). The english legal process. London: Blackstone.

Kasim, U. (2010). Karyawan diangkat direksi. Diakses dari https://www.hukumonline.com/klinik/ detail/cl4608/karyawan-diangkat-jadi-direksi.

Kusumawardani, S.I. (2013, Februari). Pengaturan kewenangan \& tanggung jawab direksi dalam perseroan terbatas (Studi perbandingan Indonesia \& Australia). Jurnal Magister Ilmu Hukum Udayana, 2(1), 1-29.

Lewis, A. (2014). Dasar-dasar hukum bisnis: Introduction to business law. Bandung: Nusa Media.
Mc Gee, A., Williams, C., \& Scantan, G. (2005). The law of business organisations. Exeter: Law Matters Publishing.

Mertokusumo, S. (2009). Hukum acara perdata Indonesia. Yogyakarta: Liberty. . (2010). Mengenal hukum: Suatu pengantar. Yogyakarta: Cahaya Atma Pustaka.

Muhammad, A. (2014). Hukum perdata Indonesia. Bandung: Citra Aditya Bakti.

Pramono, N. (2007, Desember). Tanggung jawab \& kewajiban pengurus PT (bank) menurut UU No 40 Tahun 2007 tentang Perseoran Terbatas. Buletin Hukum Perbankan dan Kebanksentralan, 5(3), 15-30.

Raffles. (2010, Juli). Eksistensi \& tanggung jawab direksi menurut Undang-Undang Nomor 40 Tahun 2007 tentang Perseroan Terbatas. Inovatif: Jurnal Ilmu Hukum, 2(4), 67-73.

Retnowulan, Sutantio, \& Oeripkartawinata, I. (2005). Hukum acara perdata dalam teori \& praktek. Bandung: Mandar Maju.

Soekanto, S. (2012). Pengantar penelitian hukum. Jakarta: Universitas Indonesia Press.

Soekanto, S., \& Mamudji, S. (2011). Penelitian hukum normatif: Suatu tinjauan singkat. Jakarta: PT Raja Grafindo Persada.

Subekti, R. (1977). Hukum acara perdata. Bandung: Binacipta.

Warsito, I.A. (2016). Hukum perdata Indonesia. Yogyakarta: Pohon Cahaya.

Widjaya, I.G.R. (2000). Hukum perusahaan: UU \& peraturan pelaksana di bidang usaha. Jakarta: Megapoint.

Woon, W. (1998). Company law. Singapore: Longman Singapore Publisher Ptc Ltd. 